\title{
The NEIL1 G83D germline DNA glycosylase variant induces genomic instability and cellular transformation
}

\author{
Heather A. Galick ${ }^{1}$, Carolyn G. Marsden ${ }^{1}$, Scott Kathe ${ }^{1}$, Julie A. Dragon ${ }^{1}$, Lindsay \\ Volk $^{3}$, Antonia A. Nemec ${ }^{4}$, Susan S. Wallace ${ }^{1}$, Aishwarya Prakash ${ }^{5}$, Sylvie Doublié ${ }^{1}$ \\ and Joann B. Sweasy ${ }^{1,2}$ \\ ${ }^{1}$ Department of Microbiology and Molecular Genetics, The Markey Center for Molecular Genetics, University of Vermont, \\ Burlington, VT, 05405, USA \\ ${ }^{2}$ Department of Therapeutic Radiology, Yale University School of Medicine, New Haven, CT, 06510, USA \\ ${ }^{3}$ Present address: University of New Mexico, Health Sciences Center, Albuquerque, NM, 87131, USA \\ ${ }^{4}$ Department of Biomedical Sciences, Florida State University, Tallahassee, FL, 32306, USA \\ ${ }^{5}$ Present address: University of South Alabama, Mitchell Cancer Institute, Mobile, AL, 36604, USA \\ Correspondence to: Joann B. Sweasy, email: joann.sweasy@yale.edu \\ Keywords base excision repair, genomic instability, replication fork collapse, DNA glycosylase, mutagenesis \\ Received: April 13, $2017 \quad$ Accepted: August 04, $2017 \quad$ Published: September 08, 2017 \\ Copyright: Galick et al. This is an open-access article distributed under the terms of the Creative Commons Attribution License 3.0 \\ (CC BY 3.0), which permits unrestricted use, distribution, and reproduction in any medium, provided the original author and source \\ are credited.
}

\section{ABSTRACT}

Base excision repair (BER) is a key genome maintenance pathway. The NEIL1 DNA glycosylase recognizes oxidized bases, and likely removes damage in advance of the replication fork. The rs5745906 SNP of the NEIL1 gene is a rare human germline variant that encodes the NEIL1 G83D protein, which is devoid of DNA glycosylase activity. Here we show that expression of G83D NEIL1 in MCF10A immortalized but non-transformed mammary epithelial cells leads to replication fork stress. Upon treatment with hydrogen peroxide, we observe increased levels of stalled replication forks in cells expressing G83D NEIL1 versus cells expressing the wild-type (WT) protein. Double-strand breaks (DSBs) arise in G83D-expressing cells during the $S$ and $\mathrm{G} 2 / \mathrm{M}$ phases of the cell cycle. Interestingly, these breaks result in genomic instability in the form of high levels of chromosomal aberrations and micronuclei. Cells expressing G83D also grow in an anchorage independent manner, suggesting that the genomic instability results in a carcinogenic phenotype. Our results are consistent with the idea that an inability to remove oxidative damage in an efficient manner at the replication fork leads to genomic instability and mutagenesis. We suggest that individuals who harbor the G83D NEIL1 variant face an increased risk for human cancer.

\section{INTRODUCTION}

Base excision repair is critically important for maintaining genomic stability because it repairs at least 20,000-50,000 lesions per cell per day that arise from the inherent instability of DNA and the presence of reactive oxygen and nitrogen species (RONs) (for a review see [1]). BER is initiated by DNA glycosylases that recognize and remove specific types of oxidized and alkylated bases in DNA (for a review see [2]). Apurinic/apyriminidinic endonuclease I (APE I) recognizes and incises the abasic site generated by a monofunctional DNA glycosylase, leaving a single nucleotide gap with a $3^{\prime} \mathrm{OH}$ and a 5 '-deoxyribose phosphate (dRP) group. This gap is filled in by DNA polymerase beta ( $p o l \beta)$, which also removes the 5 ' $\mathrm{dRP}$, and DNA ligase $3 \alpha$ (LIG3 $\alpha$ ) in complex with X-Ray Cross-Complimenting 1 (XRCC1) seals the nick (for a review see [3]). Bifunctional glycosylases, which usually recognize oxidative lesions, generate an abasic site and their associated lyase activity cleaves the DNA 
backbone via $\beta$-elimination to generate a 3 ' $\mathrm{dRP}$ and a 5 'phosphate. APE1 then catalyzes removal of the 3'dRP, leaving a $3^{\prime} \mathrm{OH}$. Pol $\beta$ binds to this substrate and fills in the resulting single nucleotide gap. In both cases, the XRCC1/ Ligase IIIa or XRCC1/Ligase I complex catalyzes ligation of the resulting ends. An alternative BER pathway, that does not depend on APE1, is utilized when the NEIL glycosylases initiate repair [4]. NEIL1 and NEIL2 catalyze excision of the damaged base via $\beta, \delta$ elimination, leaving a 3'phosphate and a 5'phosphate. The 3'phosphate is removed by polynucleotide kinase, leaving a gap that is most often filled by pol $\beta$, followed by ligation. Although NEIL3 exhibits weak lyase activity in the form of $\beta$-elimination, the base excision reaction is significantly more efficient than its lyase activity, suggesting that it functions predominantly as a monfunctional enzyme $[5,6]$.

The NEIL1 DNA glycosylase is a bifunctional enzyme that recognizes oxidized pyrimidines and formamidopyrimidines, and appears to excise lesions ahead of the replication fork [4, 7-12]. The rs5745906 SNP of the NEIL1 gene has been identified predominantly in Europeans and African Americans, has a minor allele frequency of $<0.01$, and is a $\mathrm{G}$ to $\mathrm{A}$ base substitution that results in a Gly83 to Asp83 (G83D) mutation. This variant was identified in patients with primary sclerosing cholangitis and cholangiocarcinoma [13]. We have previously shown that unlike WT NEIL1, the G83D variant is not able to excise oxidized bases efficiently due to a shift in the void-filling Met81 residue that stabilizes the DNA duplex once a damaged base has been extruded into the glycosylase substrate binding pocket [14]. Not surprisingly, the G83D variant is an inactive DNA glycosylase on most oxidized bases with the exception of spiroiminodihydantoin (Sp) and guanidinohydantoin (Gh), which can form stable extrahelical structures [14-17]. However, the recombinant NEIL1 G83D DNA glycosylase appears to be properly folded as it retains its lyase activity and is able to bind to substrates containing a thymine glycol (Tg):A base-pair $[14,15]$. It has also been shown that NEIL1 G83D exhibits a shorter retention time at laserinduced oxidative damage, but an increased retention time at psoralen crosslinks compared to WT NEIL1 [18].

Given the role of oxidative DNA damage repair in genome maintenance and the hypothesis that BER is a tumor suppressor mechanism [19], we wished to determine whether the G83D NEIL1 variant induces an oncogenic phenotype in cells. We found that expression of G83D in MCF10A immortal human breast epithelial cells induces replication stress, resulting in genomic instability and cellular transformation. These phenotypes likely arise due to an inability of G83D to remove oxidative DNA damage at the replication fork. Our results are consistent with the idea that individuals who harbor the G83D NEIL1 variant are at increased risk for cancer.

\section{RESULTS}

\section{NEIL1 G83D acts in a dominant manner in vitro}

G83D is deficient for DNA glycosylase activity but is able to bind to DNA with a Tg:A base pair in vitro and exhibits increased retention time at psoralen crosslinks $[14,18]$. Therefore, the presence of G83D in a DNA glycosylase reaction with WT NEIL1 could result in decreased enzymatic activity if it bound to and shielded Tg:A base pairs from excision by WT NEIL1. We expressed and pulled down NEIL1 WT and G83D from HEK-293T cells as described [10], and performed DNA glycosylase assays with a DNA substrate containing a Tg:A base pair as described in the Methods section. We demonstrate that WT NEIL1 has significantly greater activity than the G83D protein in this assay, as shown in Figure 1A (compare 10:0 vs 0:10 ratios of WT to G83D NEIL1, respectively; $p<0.0001$ ) (See Supplementary Figure 1 for quantification of proteins). A mixture of 5:5 WT and G83D proteins has significantly less activity than WT protein alone (compare 5:5 vs 10:0; $p \leq 0.01$ ). Similar results are observed in mixing experiments with purified NEIL1 protein (Figure 1B). In summary, our results suggest that G83D acts in a dominant or co-dominant manner to WT during an in vitro DNA glycosylase assay and that its presence can impact the overall DNA glycosylase activity in the reaction, at least against the $\mathrm{Tg}$ substrate.

\section{Replication stress is present in cells expressing NEIL1 G83D}

It has been proposed that NEIL1 functions ahead of replication forks to remove replication blocking oxidative lesions, acting as a "cowcatcher" [10], using a form of long-patch BER. Because G83D interferes with the removal of Tg by WT NEIL1 in an in vitro glycosylase reaction, we reasoned that higher levels of replication stress would be present in cells expressing G83D than in WT cells. We first expressed either NEIL1 WT or G83D in MCF10A immortal but non-transformed breast epithelial cells using the pRVY-TET vector [20, 21]. Briefly, we subcloned either hemagglutinin (HA)tagged WT or cDNA encoding the NEIL1 G83D variant into the pRVYTET vector, prepared retrovirus, and infected MCF10A human breast epithelial cells, which endogenously express WT NEIL1 DNA glycosylase. Tagging the proteins with the HA epitope enabled us to distinguish endogenous WT from exogenous protein. We selected independent pools of MCF10A cells exogenously expressing equivalent quantities of either NEIL1 WT or NEIL1 G83D (Supplementary Figure 2) as described [22] [20].

Next, to determine if replication stress is present at higher levels in G83D-expressing cells, we performed 
DNA fiber assays as we previously described [23] [24], in the absence and presence of $\mathrm{H}_{2} \mathrm{O}_{2}$, which was used to induce oxidative base damage. We first labeled the DNA of replicating cells for 30 minutes with IdU (red), and then treated with $\mathrm{H}_{2} \mathrm{O}_{2}$ to induce oxidative DNA damage (Figure 2A). After treatment, we labeled the DNA with CIdU (green) to detect forks that continued to replicate, most likely as a result of DNA repair. Our results show that cells expressing G83D have significantly increased levels of stalled replication forks when compared to cells expressing WT NEIL1 in the presence of oxidative DNA damage induced by $\mathrm{H}_{2} \mathrm{O}_{2}$ (Figure $2 \mathrm{~B}$ and $2 \mathrm{C}$ ). In addition, we observe significantly lower levels of newly initiated forks in cells expressing G83D versus WT NEIL1, both in the absence and presence of induced oxidative DNA damage (Figure 2B and 2D). Increased levels of stalled forks and decreased levels of newly initiated forks in G83D-expressing cells indicate that replication stress is present in these cells. Next, we quantified the numbers of $\gamma \mathrm{H} 2 \mathrm{AX}$ foci that colocalize with PCNA foci as another indicator of replication stress. Importantly, cells expressing G83D exhibit increased levels of colocalization of $\gamma \mathrm{H} 2 \mathrm{AX}$ and PCNA compared with WT cells, indicative of replication stress and perhaps the presence of DNA double-strand breaks (DSBs) at the replication fork (Figure 3).

Next, we characterized the presence of DSBs as a function of cell cycle phase. We synchronized cells for 24 hours by serum and growth factor deprivation, followed by growth in complete medium for 18 hours to reach $\mathrm{S}$ phase (Supplementary Figure 3). We then treated the cells with $\mathrm{H}_{2} \mathrm{O}_{2}$ during $\mathrm{S}$ phase and quantified the levels of $\gamma \mathrm{H} 2 \mathrm{AX}$ as a function of the cell cycle phase. As shown in Figure 4, we observed significantly increased levels of $\gamma \mathrm{H} 2 \mathrm{AX}$ during both $\mathrm{S}$ and $\mathrm{G} 2 / \mathrm{M}$ phases in cells expressing G83D versus WT immediately after treatment with $\mathrm{H}_{2} \mathrm{O}_{2}$. However, both G83D- and WT-expressing cells possessed similar levels of $\gamma \mathrm{H} 2 \mathrm{AX}$ in S phase after 2 hours of recovery from treatment with $\mathrm{H}_{2} \mathrm{O}_{2}$. After 6 hours of recovery from treatment, cells expressing G83D exhibited significantly increased levels of $\gamma \mathrm{H} 2 \mathrm{AX}$ compared to WT cells during the G2/M phase of the cell cycle. To provide additional evidence for the presence of DSBs in the cells expressing G83D, we stained cells with antisera raised against $53 \mathrm{bp} 1$. We demonstrate that there are greater levels of 53bp1 foci, marking DSBs, in cells expressing

\section{A. NEIL1 from HEK-293T cells}

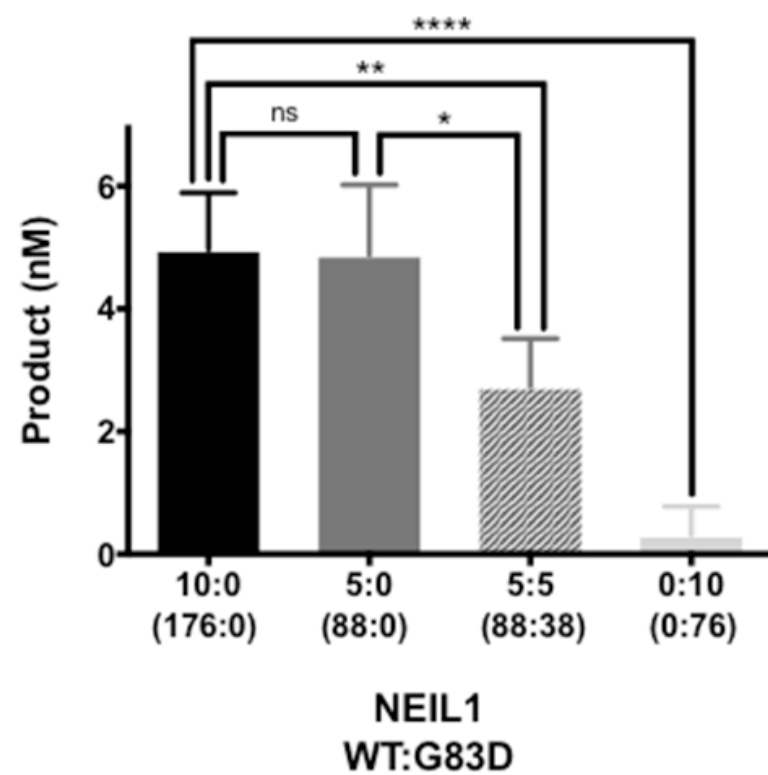

\section{B. Purified his-tagged NEIL1}

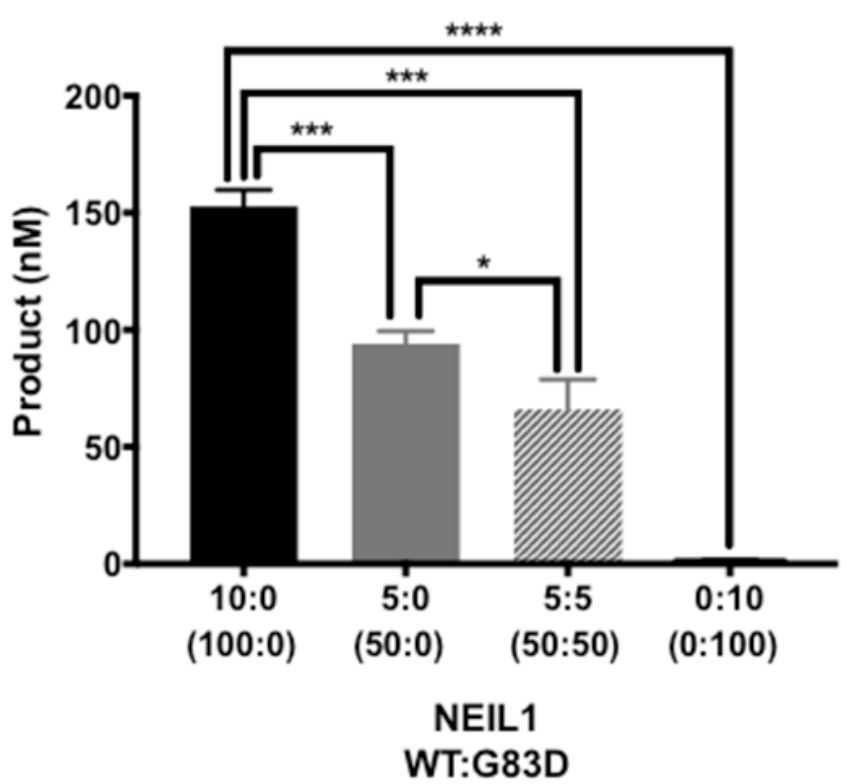

Figure 1: G83D is dominant to WT NEIL1 in vitro. (A) The WT and G83D NEIL1 DNA glycosylases were expressed in and purified from HEK293T cells as described in Methods. Glycosylase reactions were performed in a total volume of $20 \mu \mathrm{L}$, as described in Methods, using only WT, G83D, or mixtures of WT and G83D as indicated by the enzyme ratios on the X-axis of the graph. These ratios are expressed in volume $(\mu \mathrm{l})$. Subsequent quantitative western blotting, an example of which is shown in Supplementary Figure 1, revealed that 10:0 WT:G83D is $176 \mathrm{nM}$ WT:0 nM G83D; 5:0 WT: G83D is $88 \mathrm{nM}$ WT to $0 \mathrm{nM} \mathrm{G83D;} 5: 5 \mathrm{WT}:$ G83D is $88 \mathrm{nM}$ WT : $37.5 \mathrm{nM}$ G83D; and 0:10 WT:G83D is $0 \mathrm{nM}$ WT to $75 \mathrm{nM} \mathrm{G83D}{ }^{*} \mathrm{p} \leq 0.05, * * \mathrm{p} \leq 0.01, * * * \mathrm{p} \leq 0.001$, unpaired t-test. (B) Histidine-tagged (histagged) NEIL1-WT and G83D were purified from E. coli as described [14]. Glycosylase reactions with purified proteins were performed as described in Materials and Methods. The ratios of WT:G83D are based upon active fractions as described in Materials and Methods. 


\begin{tabular}{|lll|}
\hline A IdU & $\mathrm{H}_{2} \mathrm{O}_{2}$ & CldU \\
\hline $30 \mathrm{~min}$ & $30 \mathrm{~min}$ & $30 \mathrm{~min}$ \\
\hline
\end{tabular}
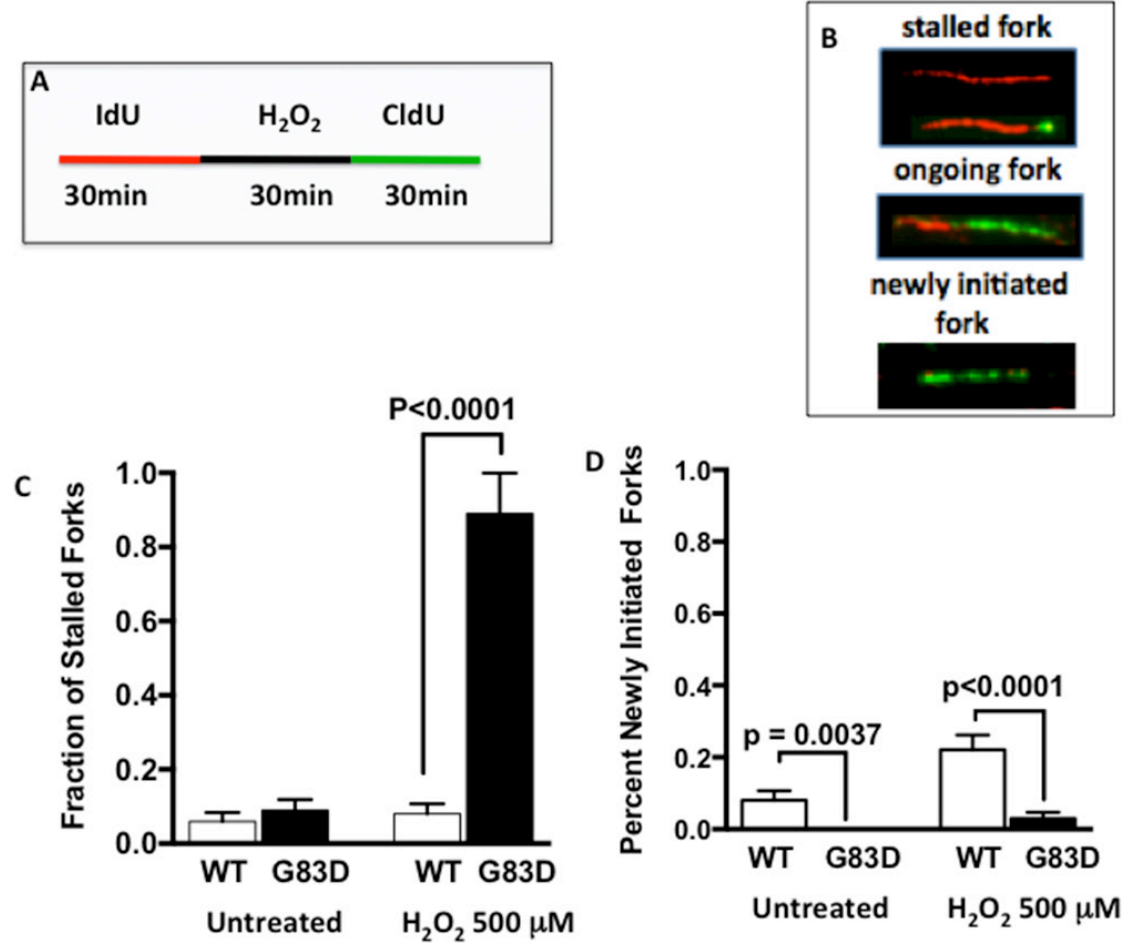

Figure 2: Expression of G83D NEIL1 induces replication stress. We performed DNA fiber assays in the absence and presence of $\mathrm{H}_{2} \mathrm{O}_{2}$, which was used to induce oxidative base damage. (A) We first labeled the DNA of replicating cells for 30 minutes with IdU (red), and then treated or not with $\mathrm{H}_{2} \mathrm{O}_{2}$ to induce oxidative DNA damage. After treatment, we labeled the DNA with CIdU (green) to detect forks that continued to replicate. (B) Examples of images of stalled, ongoing, and newly initiated replication forks. (C) Quantification of spontaneous and $\mathrm{H}_{2} \mathrm{O}_{2}$-induced stalled forks. (D) Quantification of newly initiated forks. Unpaired t-tests were used to determine levels of significance.

A

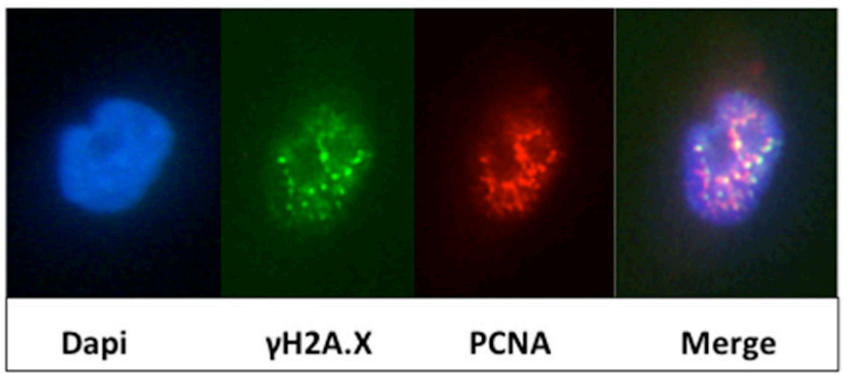

B

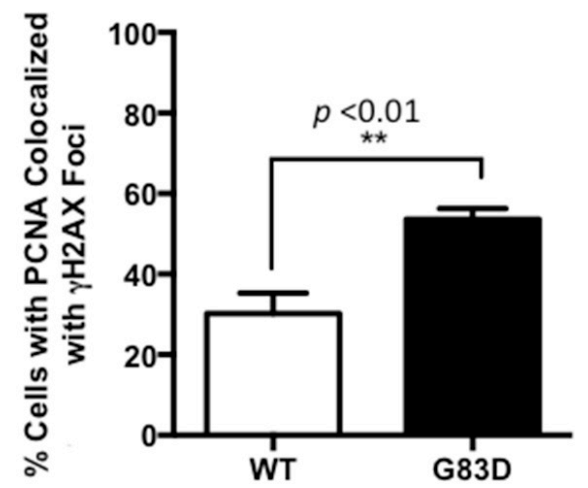

Figure 3: PCNA and $\gamma \mathbf{H 2 A X}$ foci colocalize in cells expressing NEIL1 G83D. Cells were treated with $0.2 \mathrm{mM} \mathrm{H}_{2} \mathrm{O}_{2}$ and analyzed as described in methods. Although colocalization of PCNA and $\gamma \mathrm{H} 2 \mathrm{AX}$ is observed in cells expressing WT NEIL1, greater levels of colocalization is observed in cells expressing G83D NEIL1. (A) Two examples of PCNA and $\gamma \mathrm{H} 2 \mathrm{AX}$ in the nucleus of a cell expressing G83D. (B) Quantification of cells exhibiting foci of PCNA that colocalize with $\gamma \mathrm{H} 2 \mathrm{AX}$. Unpaired t-tests were used to determine levels of significance. 
G83D versus WT NEIL1, at 6 and 8 hours after treatment with hydrogen peroxide (Figure 5). In combination, these results suggest that higher levels of DSBs arise in cells expressing G83D compared to WT NEIL1.

Replication stress is also known to be associated with phosphorylation of the CHEK1 (Chk1) kinase and subsequent initiation of cell cycle checkpoints. We show that Chk1 is phosphorylated in both WT and G83D cells to similar levels after treatment with hydrogen peroxide (Supplementary Figure 4). However, we observe that phosphorylation of CHEK2 (Chk2) kinase is increased in cells expressing G83D after treatment with hydrogen peroxide (Figure 6), signifying the presence of DSBs.

\section{Expression of NEIL1G83D in MCF10A cells induces genomic instability and mutagenesis}

Replication stress is associated with genomic instability [25-27], especially arising during G2/M in the form of micronuclei. Because G83D NEIL1 acts in a dominant negative or co-dominant manner to WT in an in vitro DNA glycosylase assay and its expression induces replication stress, we reasoned that expression of NEIL1 G83D DNA glycosylase in the presence of WT NEIL1 would result in genomic instability and/ or mutagenesis. To determine if expression of G83D induces genomic instability, we prepared and analyzed metaphase spreads of MCF10A cells alone or expressing either G83D or WT NEIL1. Expression of G83D leads to significantly increased levels of chromosomal fragments when compared to cells expressing WT NEIL1 as well as increased levels of total aberrations when compared to WT NEIL1 and MCF10A cells alone (Figure 7A and 7B). We also determined whether the presence of G83D results in an increased mutation frequency by assessing the ability of MCF10A cells expressing either G83D or WT NEIL1 to grow in medium containing ouabain. Ouabain binds to and inhibits the $\mathrm{Na}^{+} / \mathrm{K}^{+}$-ATPase sodium potassium ion pump, leading to accumulation of intracellular sodium and eventual cell death. Mutations in the $\mathrm{Na}^{+} / \mathrm{K}^{+}$-ATPase sodium potassium ion pump can result in ouabain resistance, therefore increased ouabain resistance serves as a marker for increased mutagenesis. As shown in Figure 7C, cells expressing NEIL1 G83D exhibited a significantly increased mutation frequency when compared to WT cells as monitored by ouabain resistance. Increased formation of micronuclei is also reflective of underlying replication stress and genomic instability. Interestingly, cells that express G83D exhibit significantly higher levels of micronuclei than WTexpressing cells, as shown in Figure 7D. Therefore, expression of G83D in MCF10A cells induces genomic instability and an increased mutation frequency when compared to cells expressing WT NEIL1.

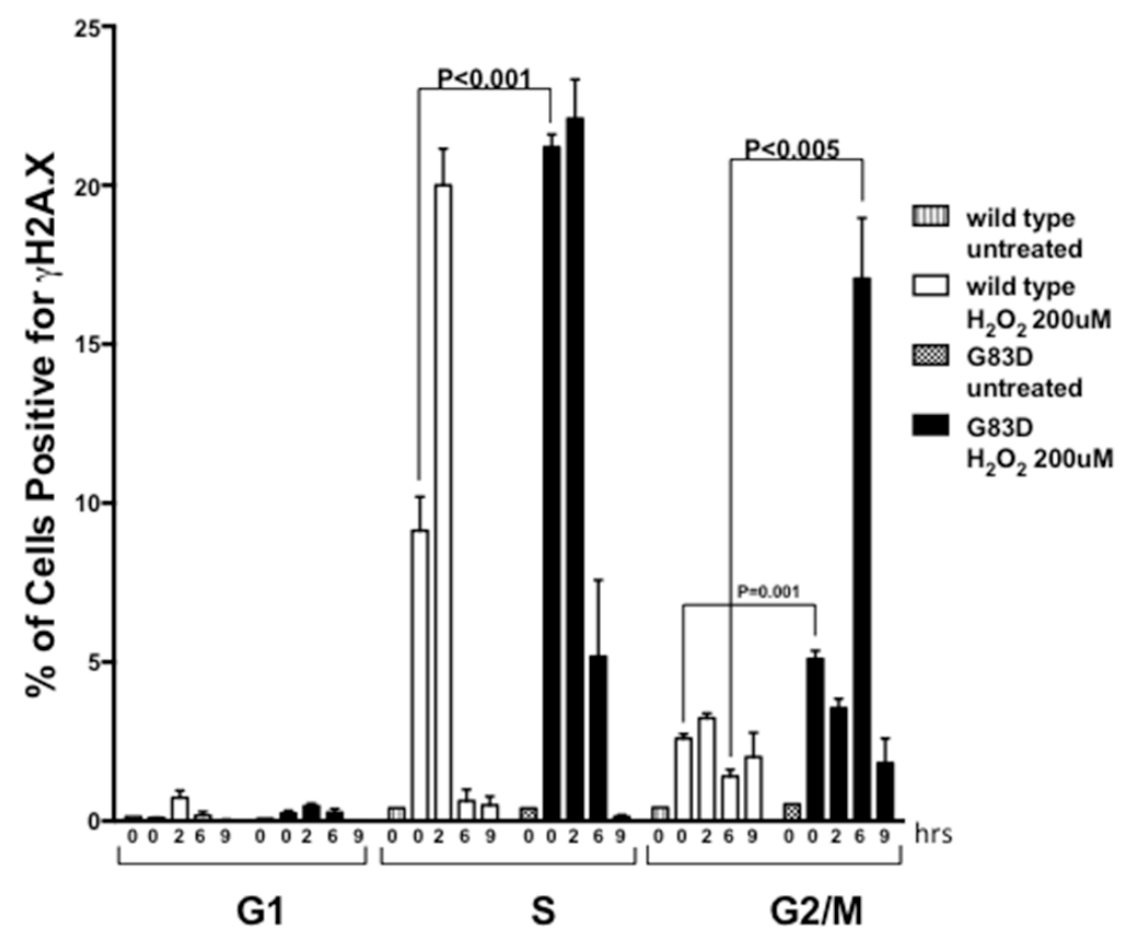

Figure 4: NEIL1 G83D induces DSBs during $\mathbf{S}$ and G2/M phases of the cell cycle. Cells were synchronized as described in methods, released, and treated (or not) with $0.2 \mathrm{mM} \mathrm{H}_{2} \mathrm{O}_{2}$. Cells were fixed and stained with antisera against $\gamma \mathrm{H} 2 \mathrm{AX} / \mathrm{FITC}$ to monitor DSBs, and with Propidium Iodide (PI) to monitor the phase of the cell cycle. Flow cytometry was then performed. Unpaired t-tests were used to determine levels of significance after various hours of recovery. 


\section{NEIL1 G83D induces cellular transformation}

Genomic instability, mutagenesis, and the presence of micronuclei are all linked to carcinogenic phenotypes. Therefore, we assessed the ability of G83D- versus WT-expressing cells to grow as colonies in soft agar, termed anchorage independent growth. We passaged the cells in the absence of dox and characterized anchorage independent growth. At passage 12, cells expressing G83D together with endogenous WT NEIL1 exhibit significantly increased levels of anchorage independent growth compared with cells expressing WT NEIL1 alone (Figure 8).
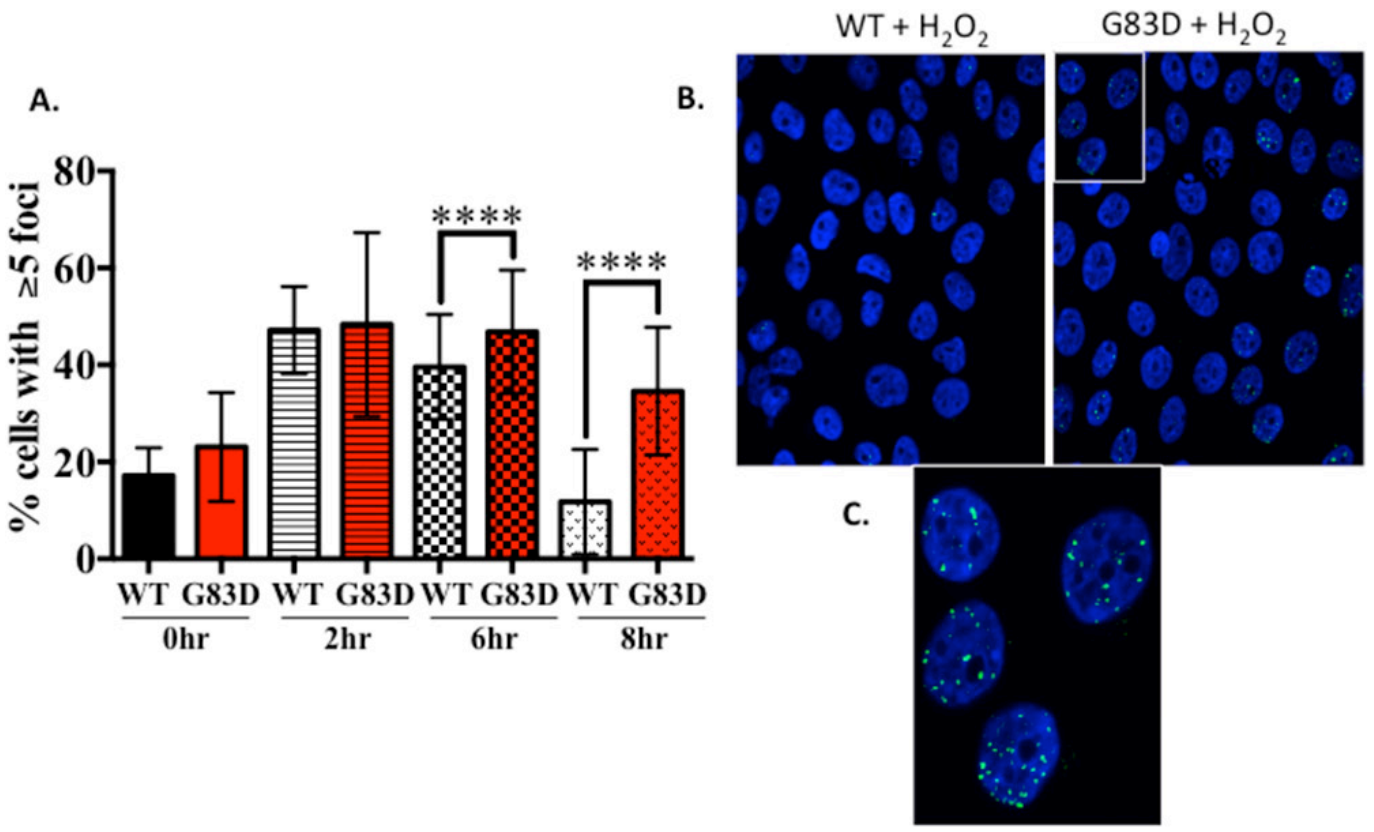

$\mathrm{G} 83 \mathrm{D}+\mathrm{H}_{2} \mathrm{O}_{2}$ (inset)

Figure 5: The levels of 53bp1 are higher in cells expressing G83D versus WT NEIL1. MCF10A pools expressing NEIL1 WT or G83D were treated $200 \mu \mathrm{M} \mathrm{H}_{2} \mathrm{O}_{2}$ for $30 \mathrm{~m}$ then fixed at $0,2,6$ and $8 \mathrm{hrs}$ post-treatment and immunofluorescence was performed. Cells were labeled with a 53BP1 antibody (green) then mounted in Prolong Gold mounting media containing DAPI (blue, nuclei). Labeled cells were visualized using a Zeiss LSM 510 META confocal imaging system. (A) The number of nuclei with greater than 5 foci of 53BP1 was counted. The data are graphed as mean $\pm \mathrm{SD}(\mathrm{n}>500$ nuclei) $* * * * \mathrm{p}<0.0001$. (B) Representative images of 53BP1 foci in MCF10A NEIL1 WT and G83D G151D expressing pools at 8hrs post-treatment. (C) Expanded inset of nuclei outlined in part B.

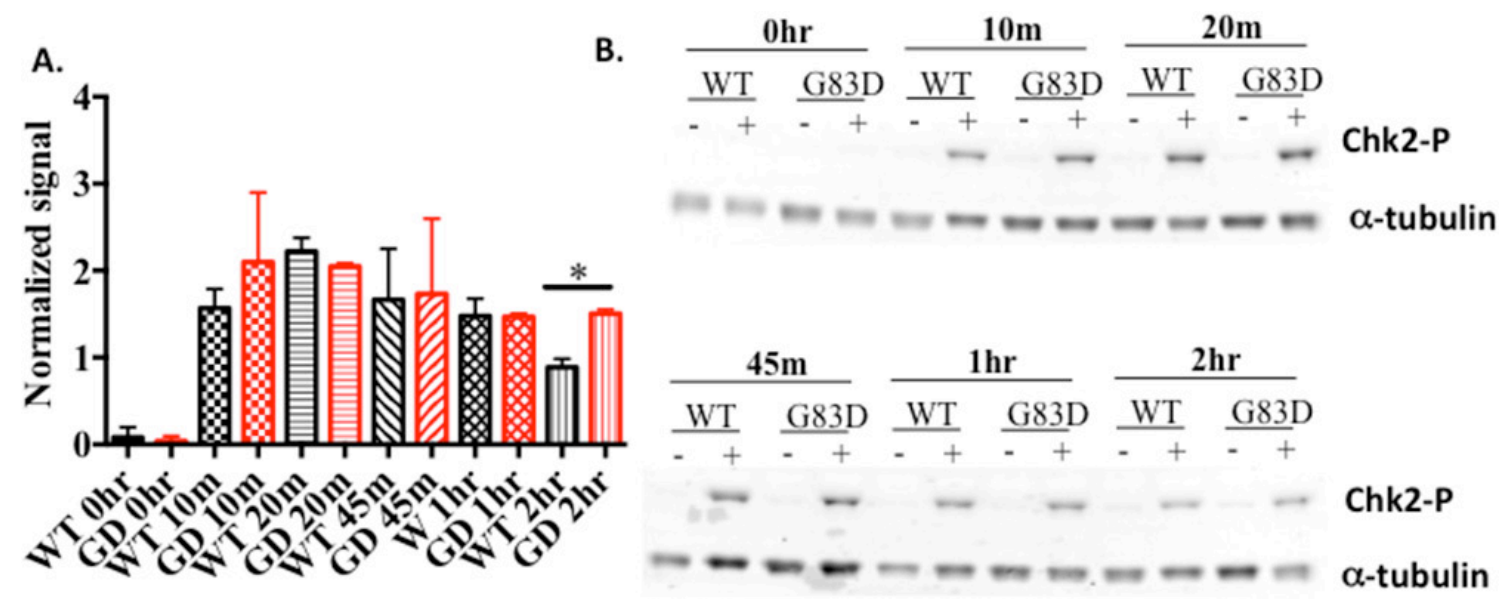

Figure 6: Chk2 is phosphorylated to greater levels in cells expressing G83D. (A) Quantification of levels of phosphorylated Chk2, normalized to alpha tubulin, at various times after treatment with hydrogen peroxide. (B) Example of a western blot using anti-Chk2 (Ser 68). 


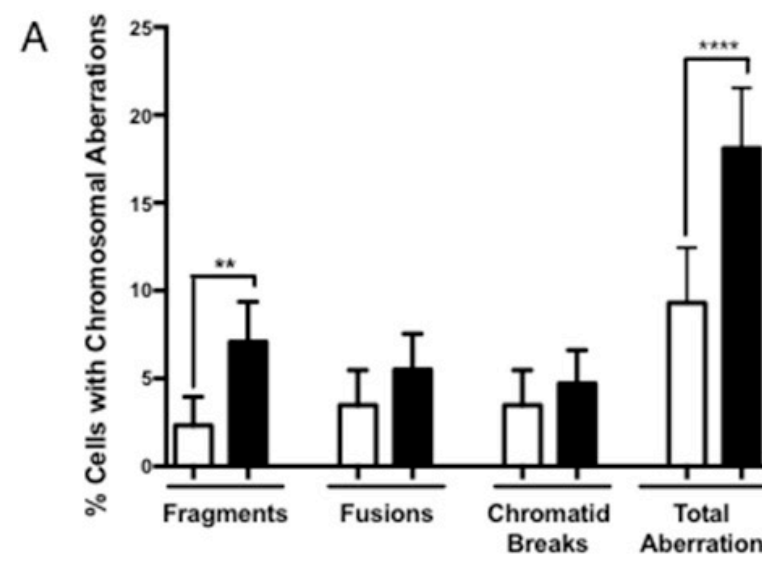

NEIL1 WT $(n=86)$

NEIL1 G83D ( $n=127)$
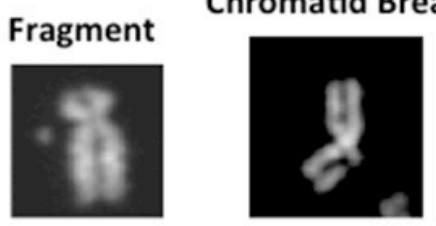

Fusion

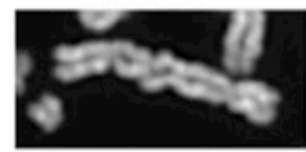

C
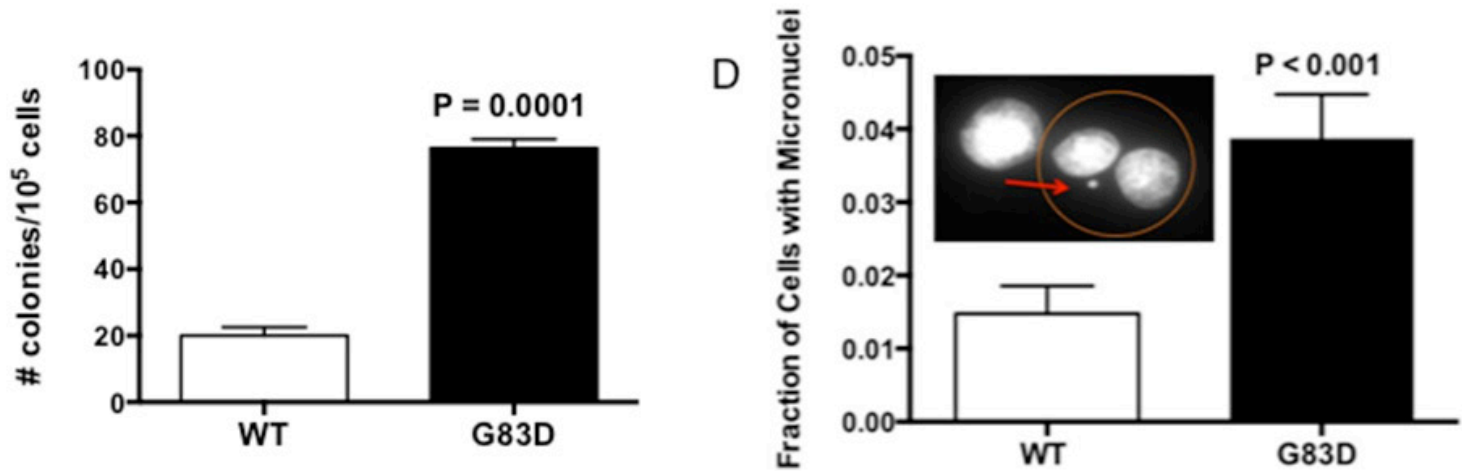

Figure 7: G83D induces genomic instability and mutagenesis. (A) Assessment of chromosomal aberrations. Experiments were performed as described in methods using cells at passage 2. Expression of the G83D variant induces significantly increased numbers of fragments and total aberrations compared to WT. At least 50 nuclei were analyzed. $* * p=0.007 ; * * * * p<0.0001$. (B) Examples of types of chromosomal aberrations scored in the assay. (C) Determination of mutagenic potential. Oubain resistance was scored in cells at passage 2 as described in methods. Expression of G83D induces point mutations at a significantly increased frequency over that of WT. (D) Measurement of micronucleus formation. Micronuclei were scored as described in methods. The G83D cells exhibit significantly increased levels of micronuclei when compared with WT NEIL1-expressing cells.

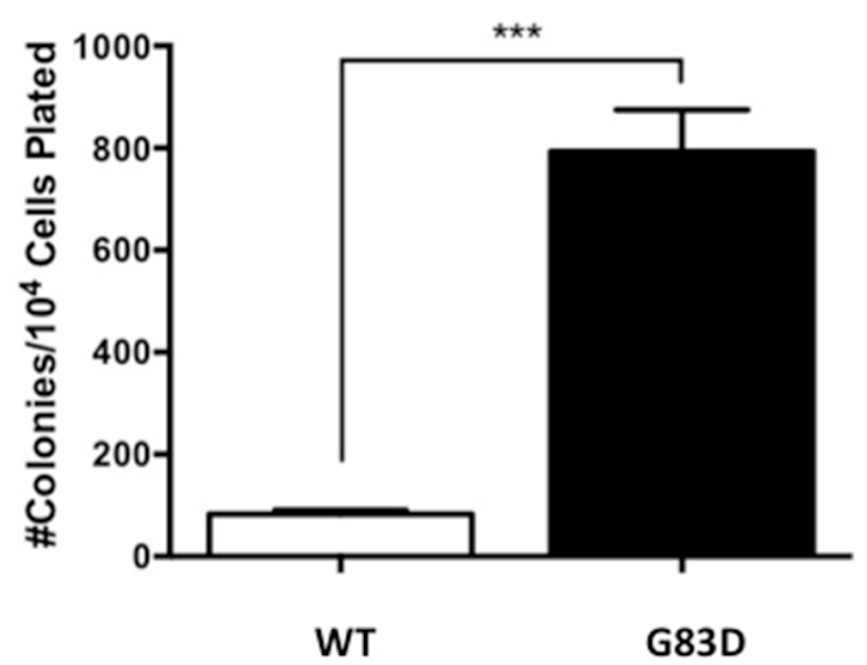

Figure 8: G83D expression induces anchorage-independent growth. After selection of stable pools, the cells were passaged every 3-4 days and on every fourth passage plated in soft agar to assess anchorage-independent growth. Significantly greater numbers of colonies grow when cells express G83D NEIL1 versus WT at passage 12. Previous to this passage very few colonies growing in an anchorage-independent manner were observed. 


\section{DISCUSSION}

The overall goal of this study was to determine if the NEIL1 G83D germline variant has a functional phenotype that is related to cancer. We found that expression of this variant in the presence of the WT NEIL1 DNA glycosylase in human MCF10A immortalized breast epithelial cells leads to increased levels of replication stress resulting in genomic instability and an increased frequency of mutagenesis. Importantly, we also show that cells expressing G83D can grow in an anchorage-independent manner after several passages. These phenotypes are often associated with carcinogenesis and suggest that individuals who harbor the NEIL1 G83D variant may be at increased risk for cancer.

\section{NEIL1 G83D is dominant to WT NEIL1 in vitro}

Upon co-incubation of G83D and WT NEIL1, we show that G83D blocks or interferes with the removal of $\mathrm{Tg}$, a replication-blocking lesion. Because G83D is able to bind to Tg but not remove it [14], we suggest that even in the presence of WT NEIL1, G83D binds to Tg, and shields it from excision by WT NEIL1. We observe this to be the case even when the concentration of G83D is less than half that of WT NEIL1. We suggest that G83D also binds to lesions, including Tg, arising in the DNA of cells, probably shielding the lesions from immediate excision by WT NEIL1 and perhaps other DNA glycosylases.

\section{The presence of G83D NEIL1 interferes with BER at the fork}

Mitra and colleagues [10] proposed that a major role of NEIL1 DNA glycosylase is to act as a "cowcatcher" ahead of the replication fork. Specifically, it is proposed that NEIL1 binds to oxidative lesions in single-stranded DNA (ssDNA) proximal to the fork and that the presence of RPA inhibits excision of the damaged base and cutting of the DNA backbone, limiting DSB formation. It is suggested that the binding of NEIL1 results in replication fork reversal and once the fork is reversed, NEIL1 excises the damaged base, cuts the DNA backbone, and utilizes long patch BER involving an interaction with DNA polymerase $\delta(\mathrm{Pol} \delta$ ) to complete DNA repair, allowing replication fork progression. In fact, depletion of NEIL1 significantly slows replication fork progression [10].

In cells expressing the glycosylase-deficient G83D enzyme, we observe a significant increase in the levels of stalled replication forks over what is seen in cells expressing WT NEIL1 in the presence of oxidative DNA damage induced by $\mathrm{H}_{2} \mathrm{O}_{2}$. We also observe increased levels of $\gamma \mathrm{H} 2 \mathrm{AX}$ in cells expressing exogenous G83D versus WT NEIL1 during S phase immediately after $\mathrm{H}_{2} \mathrm{O}_{2}$ treatment, and during G2/M six hours after treatment. The results are consistent with the suggestion that DSBs arise during replication and are likely to be present at replication forks at higher levels in the cells expressing G83D. Our results are also consistent with the idea that DSBs arising during $\mathrm{S}$ phase may not be repaired until the cells reach the G2/M phase of the cell cycle.

NEIL1 G83D is able to bind to Tg, a replicationblocking lesion. Binding of $\mathrm{Tg}$ and perhaps other replication blocking lesions by G83D may shield them from WT NEIL1 and perhaps other DNA glycosylases with overlapping substrate specificity. An inability to remove replication-blocking lesions would not promote repair by long patch BER, leading to irreversible stalling of the replication fork, perhaps prolonged fork regression and subsequent processing by nucleases, for example, MUS81 or the SLX4 complex [28] (for a review see [29]), leading to replication fork collapse. Interestingly, we observe increased levels of Chk2, but not Chk1, phosphorylation in cells expressing G83D. This is consistent with the presence of prolonged fork regression catalyzed by FBH1 helicase and subsequent MUS81-dependent processing of the regressed fork to generate DSBs, which triggers phosphorylation of Chk2 [30-32]. Alternatively, as G83D and WT NEIL1 are both present in the cells, G83D and WT NEIL1 may be in rapid exchange of binding to the replication-blocking lesion. This may alter replication fork dynamics in such a way that base excision occurs in a nonregressed fork, leading to induction of a DSB.

The DSBs that arise as a result of replication fork collapse or inappropriate base excision at the replication fork likely give rise to the chromosomal aberrations and micronuclei that we find at increased levels in cells expressing NEIL1 G83D. We suggest that these types of genomic instability arise and accumulate during passaging of the cells expressing NEIL1 G83D and together with selection for highly proliferative cells during passaging, eventually result in the ability of the cells to grow in an anchorage independent manner.

\section{Increased levels of mutagenesis may also promote anchorage independent growth}

Anchorage of cells to the extracellular matrix (ECM) regulates both proliferation and cell division (for a review see [33]). Anchorage-independent growth results when cells are able to grow and divide in the absence of ECM, as a result of oncogenic mutations, with some of the most well known mutations occurring in the $R A S$ oncogenes. In addition to chromosomal aberrations, we also observe significantly increased levels of point mutations arising in cells expressing NEIL1 G83D. We suggest that some of the oxidized bases that are not removed when G83D is present in the cells are bypassed by translesion DNA polymerases at the replication fork, resulting in mutations in a form of damage tolerance. Some of these mutations may arise in oncogenes or other genes that lead to circumvention of the requirement for the 
cells to be anchored during proliferation and cytokinesis, ultimately resulting in anchorage independent growth.

\section{Summary}

Our results demonstrate that expression of the NEIL1 G83D glycosylase-deficient enzyme in immortal but non-transformed human cells leads to the accumulation of stalled replication forks, increased levels of genomic instability and mutagenesis, resulting in cellular transformation. Our results are consistent with the suggestion that individuals who harbor the germline SNP encoding for NEIL1 G83D have increased levels of genomic instability that could predispose them to the development of cancer.

\section{MATERIALS AND METHODS}

\section{Cell lines and cell culture}

The MCF10A cells were grown as described previously [21]. The GP2-293 virus packaging cell line (Clontech) was used for retrovirus preparation. These cells were maintained in Dulbecco modified Eagle's medium (Invitrogen) supplemented with 10\% fetal bovine serum (Invitrogen), 1\% L-glutamine (Invitrogen), 1\% penicillinstreptomycin (Invitrogen) and 1 mMHEPES (Invitrogen). HEK293T cells were gown in DMEM with $110 \mathrm{mg} / \mathrm{L}$ sodium pyruvate, $6 \mathrm{mM}$ L-glutamine, $10 \%$ fetal bovine serum, and $100 \mathrm{U} / \mathrm{mL}$ penicillin-streptomycin.

\section{Cloning of NEIL1 WT and G83D and expression in MCF10A cells}

The strategy used to subclone WT and G83D NEIL1 was similar to the one described previously for NTHL1 [21]. For cell culture experiments, human NEIL1 cDNA with a C-terminal hemagglutinin (HA) tag was cloned into the pRVYTet retroviral vector as described [20]. The G83D NEIL 1 variant was introduced into the human WT NEIL1cDNA sequence using site-directed mutagenesis (Stratagene) following the manufacturer's protocols as described previously [14]. Human NEIL1 WT and G83D constructs were packaged into retrovirus using the GP2-293 packaging line as previously described [22]. Expression of exogenous HA-tagged NEIL1 was verified by Western blot using monoclonal mouse antiHA antibody(Covance). $\beta$-tubulin(Sigma-Aldrich) was used as a loading control. pHCMV1 NEIL1 MBP-His was restricted with NotI and Xhol to remove the MBP-his sequence and replaced with a FLAG sequence to create pHCMV1-NEIL1 FLAG. The pHCMV1-NEIL1G83DFlag variant plasmid was made using the Q5 SiteDirected Mutagenesis kit (New England Biolabs, NEB), following the NEB protocol with the following primers, CTCTTTTCAGCTGGTGCCCCGC forward and
TCGGACATGCCGAAGCGGAAGACC reverse. The sequences were confirmed by the University of Vermont Advanced Genome Technology Core.

\section{Expression and pull-down of NEIL1 from HEK293T cells}

HEK-293T cells were transiently transfected with the pHCMV1-NEIL1 FLAG or the pHCMV1NEIL1G83D-Flag variant plasmids using the calcium phosphate method as described (delangelab.rockefeller. edu/assets/file/293T_Tx_co-IP.pdf). HEK-293T cells were harvested approximately 48 hours after transient transfection. Media was removed from a $100 \mathrm{~mm}$ plate and cells were scraped in $10 \mathrm{mls}$ ice cold phosphate buffered saline (PBS), collected and centrifuged at 400 $\mathrm{x}$ G for 5 minutes at $4^{\circ} \mathrm{C}$, the supernatant was aspirated. The cells were lysed in $1 \mathrm{ml}$ of $50 \mathrm{mM}$ Tris (pH 7.5), $150 \mathrm{mM} \mathrm{NaCl}, 1 \mathrm{mM}$ EDTA, 1\% Triton X-100 (SIGMA lysis buffer), $1 \mathrm{mM} \mathrm{NaF}, 1 \mathrm{mM} \mathrm{Na} \mathrm{VO}_{4}, 1 \mathrm{mM}$ PMSF and Roche Complete Ultra EDTA-free protease inhibitor (according to manufacturers instructions) for 30 minutes on ice. The lysate was centrifuged at $4^{\circ} \mathrm{C}$ for 15 minutes at $19090 \times$ G, the supernatant was added to ANTI-FLAG M2 magnetic beads ( $20 \mu \mathrm{l}$, SIGMA) in $1.5 \mathrm{ml}$ microcentrifuge tubes and incubated at $4{ }^{\circ} \mathrm{C}$ for 2 hours with inversion. The microcentrifuge tubes were placed in a magnetic separator and the beads were washed twice with $500 \mu \mathrm{l}$ of $50 \mathrm{mM}$ Tris-Cl, pH 7.5 and $150 \mathrm{mM} \mathrm{NaCl}$ (tris buffered salineTBS). The NEIL1 complexes were eluted with $100 \mu$ of $100 \mu \mathrm{g} / \mathrm{ml}$ flag peptide in TBS and $10 \%$ glycerol at $4{ }^{\circ} \mathrm{C}$ for 30 minutes with inversion. The M2 magnetic beads were removed and the complexes were assayed immediately or frozen at $-80^{\circ} \mathrm{C}$.

\section{DNA glycosylase assays}

Glycosylase assays were carried out with $10 \mathrm{nM}$ Tg:A substrate. The substrate was made by labeling 1 pmol of the Tg containing oligonucleotide with T4 polynucleotide kinase (New England Biolabs) and $\gamma-{ }^{32} \mathrm{P}$ for 15 minutes at $37^{\circ} \mathrm{C}$. The reaction was stopped by the addition of $1 \mathrm{mM}$ EDTA and heating to $95^{\circ} \mathrm{C}$ for 1 minute. The DNA was ethanol precipitated and dried, 9 pmol of the $\mathrm{Tg}$ containing oligonucleotide was added along with $10 \mathrm{pmol}$ of the complementary oligonucleotide in $10 \mathrm{mM}$ Tris (pH 8.0) and $50 \mathrm{mM} \mathrm{NaCl}$ at a final concentration of $250 \mathrm{nM}$ double-stranded oligonucleotide substrate. The substrate was placed in a boiling water bath and cooled slowly to allow the DNA to anneal. The oligonucleotide sequences were as follows: the damage containing strand 5'-TGTCAATAGCAAGTgGGAGAAGTCAATCGTGAG TCT-3', the complementary strand 5'-AGACTCACGATT GACTTCTCCACTTGCTATTGACA-3'.

Glycosylase/lyase assays contained a final concentration of $10 \mathrm{nM}$ Tg:A substrate, $25 \mathrm{mM}$ Tris (pH 
7.5), $75 \mathrm{mM} \mathrm{NaCl}, 10 \mathrm{mM} \mathrm{MgCl}_{2}, 200 \mu \mathrm{g} / \mathrm{mL}$ bovine serum albumin (BSA), $1 \mathrm{mM}$ dithiothreitol (DTT) and NEIL1 immunoprecipitation elution. The assays were allowed to proceed for 60 minutes and quenched in an equal volume of formamide stop solution $(98 \%$ formamide, $0.1 \mathrm{mM}$ EDTA. $0.1 \%$ bromophenol blue and $0.1 \%$ xylene cyanol). The samples were resolved on a $12 \%$ polyacrylamide $(\mathrm{w} / \mathrm{v})$ sequencing gel, transferred to Whatman $3 \mathrm{M}$ paper, dried and exposed to a phosphor imager screen and imaged with a Pharos FX Plus Molecular Imaging System (BioRad).

Glycosylase/lyase assays with purified his-tagged NEIL1 WT and G83D were performed using the same conditions as used in the immunoprecipitation assay except that the concentration of Tg:A substrate was increased from 10 to $200 \mathrm{nM}$. A Schiff base assay was performed to determine the active fraction of NEIL WT and G83D [34].

\section{Western blotting}

To perform quantitative western blotting for NEIL1, eluted NEIL1 complexes from the FLAG tag pull down were resolved in a $10 \%$ SDS-page gel along with 100 , 200, 400, 600 and $800 \mathrm{ng}$ of His-tagged recombinant NEIL1 purified from $E$. coli as described previously [14]. The proteins were transferred to an Immobilon-FL PVDF membrane (EMD Millipore) blocked for 1 hour and probed with a rabbit polyclonal antibody to NEIL1 (Abcam), $(5 / 10,000)$ for 1 hour. The membrane was washed and incubated with IRDye 680RD goat antirabbit $\operatorname{IgG}(1 / 20,000)$ for 30 minutes. All incubations were performed at room temperature. The membrane was washed and visualized on a LiCor Odyssey CLx Infrared Imaging System. The expression levels of NEIL1 were quantified using Image Studio Software version 2.1.10. A linear regression was performed using the known amounts of the His-tagged NEIL1 and the amounts of NEIL1 WT and G83D were determined.

\section{DNA fiber assay}

This assay was performed as described [24]. Briefly, MCF10A cells expressing WT or G83D NEIL1 were grown to approximately $30-40 \%$ confluence. Cells were pulsed with $25 \mu \mathrm{M}$ IdU for 30 minutes, washed three times with PBS, and pulsed with $250 \mu \mathrm{M}$ CldU for 30 minutes. Cells were treated or not with $500 \mathrm{uM} \mathrm{H}_{2} \mathrm{O}_{2}$ for 30 minutes on ice between pulses. Cells were harvested and resuspended in PBS at a concentration of $1.7 \times 10^{6}$ cells $/ \mathrm{ml}$ and $3 \mu \mathrm{l}$ (5000 cells) of the cell suspensions were placed on glass slides and mixed with $7 \mu \mathrm{l}$ of lysis buffer (200 mM Tris, pH 7.6, $50 \mathrm{mM}$ EDTA, 0.5\%SDS) for 2 min. Slides were tilted at $20^{\circ}$ for gravity flow. The slides were fixed in a $3: 1$ solution of methanol-acetic acid for $20 \mathrm{~min}$ at $-20^{\circ} \mathrm{C}$ and treated with $2.5 \mathrm{M} \mathrm{HCL}$ for $30 \mathrm{~min}$ followed by washes with PBS before blocking in 5\% BSA for $30 \mathrm{~min}$ at $37^{\circ} \mathrm{C}$. To detect incorporated IdU and CldU, DNA fibers were incubated with mouse anti-BrdU (Becton Dikinson; 1:25) and rat anti-BrdU monoclonal antibody (Abcam; 1:400), respectively, for $1 \mathrm{~h}$ at room temperature (RT), followed by 3 washes with PBS, and incubation with sheep anti-mouse Cy3 (Sigma; 1:500) and goat antirat Alex Fluor 488 (Invitrogen 1:400) for $1 \mathrm{~h}$ at RT. The slides were mounted with Vectashield mounting medium and covered with coverslips. Images were acquired using a Zeiss microscope at 63 magnification and processed using Image J software (http://imagej.nih.gov/ij/).

\section{Anchorage-independent growth assay}

Anchorage-independent growth was assessed as previously described [20]. Briefly, 1 x $10^{4}$ MCF10A cells expressing either WT or G83D NEIL1 were mixed with media containing $0.7 \%$ noble agar (USB) and poured onto a layer of media containing $1.0 \%$ noble agar. The number of colonies present in each of ten microscope fields per well from a total of 3 wells per experiment were counted after 4 weeks of growth.

\section{Immunofluorescence}

MCF10A cells expressing WT or G83D NEIL1 were grown on glass coverslips (Sigma). Cells were fixed in a $3: 1$ solution of methanol-acetic acid for $20 \mathrm{~min}$ at $-20^{\circ} \mathrm{C}$ and permeabilized in $0.5 \%$ Triton buffer $(20 \mathrm{mM}$ HEPES, $\mathrm{pH} 7.4,50 \mathrm{mM} \mathrm{NaCl}, 3 \mathrm{mM} \mathrm{MgCl}, 300 \mathrm{mM}$ sucrose, $0.5 \%$ Triton $\mathrm{x}-100$ ) for $10 \mathrm{~min}$ at RT. Coverslips were blocked in 3\% BSA and goat serum for $30 \mathrm{~min}$ at RT and incubated with the primary antibodies, anti-PCNA (Santa Cruz) or anti- $\gamma \mathrm{H} 2 \mathrm{AX}$ (Cell Signaling) overnight at $4^{\circ} \mathrm{C}$. Coverslips were washed and incubated with secondary FITC or rhodamine antibodies. Coverslips were mounted on slides using SlowFade ${ }^{\circledR}$ Gold Antifade Mountant containing DAPI to stain the nuclei (Invitrogen). To determine if 53bp1 foci were present after induction of oxidative damage, cells were treated 0 or $200 \mu \mathrm{M} \mathrm{H}_{2} \mathrm{O}_{2}$ then allowed to recover for $0,2,6$ or $8 \mathrm{hrs}$ post-treatment. Cells were washed 2 times with PBS then fixed (4\% paraformaldehyde, $0.02 \%$ TritonX-100) for 15 minutes at room temperature. Cells were rinsed with PBS then incubated with blocking/permeabilization solution (10\% normal goat serum, $0.5 \%$ TritonX-100) for 1 hour at with gentle shaking. The blocking/permeabilization solution was then replaced with blocking/permeabilization solution containing diluted (1/500) mouse anti-human 53BP1 primary antibody (Millipore; MAB3802) and incubated overnight at $4^{\circ} \mathrm{C}$ with gentle shaking. The next day, the cells were washed with PBS $/ 0.5 \%$ TritonX-100 followed by 2 washes with PBS. Cells were then incubated with AlexaFluor 488 goat anti-mouse $\operatorname{IgG}(\mathrm{H}+\mathrm{L})$ antibody $(1 / 1000)$ (Invitrogen) diluted in blocking/permeabilization 
solution for 1 hour with gentle shaking. The cells were washed with PBS $/ 0.5 \%$ TritonX-100 followed by 2 washes with PBS then slides were mounted in Prolong Gold Antifade reagent with DAPI (Invitrogen). Cells were imaged using a Zeiss LSM 510 META confocal scanning laser microscope.

\section{Flow assay and western blotting for Chk1 and 2}

This assay was conducted essentially as described [21]. Briefly, MCF10A cells expressing WT or G83D NEIL1 were plated and synchronized by serum starvation for 48 hours, then complete media was added back and cells allowed to recover for 18 hours until entering $\mathrm{S}$-phase. Cells were then treated with $200 \mu \mathrm{M} \mathrm{H}_{2} \mathrm{O}_{2}$ on ice for 20 minutes, placed back into media and allowed to recover for the specified times. Cells were harvested on ice in cold Accutase with $5 \mathrm{mM}$ EDTA, phosphatase and protease inhibitors, washed and fixed in ice cold $70 \% \mathrm{EtOH}$ and stored at $-20^{\circ} \mathrm{C}$ for at least $30 \mathrm{~min}$ and up to a month. For flow cytometry, cells were rehydrated and resuspended in PBS $+1 \%$ BSA, $0.1 \%$ Triton X-100, $5 \mathrm{mM}$ EDTA, 3X phosphatase inhibitors and $1 \mathrm{X}$ protease inhibitors, then stained with anti-histone H2A.X antibody - ChIP Grade (ab11175) overnight at $4^{\circ} \mathrm{C}$, and then with FITC-conjugated anti-rabbit secondary antibody (Alexa 488 , BD Biosciences) for $1 \mathrm{hr}$ at room temperature, all in the same buffer. They were then washed and resuspended in 450ul BD PI/Rnase buffer with $5 \mathrm{mM}$ EDTA, 3X phosphatase inhibitors and $1 \mathrm{X}$ protease inhibitors and strained through 44 micron filter mesh into a flow cytometry tube. Fluorescence was analyzed by flow cytometry using the BD FACSCalibur and analyzed using FlowJo 8.8.6 software. To monitor phosphorylation of Chk1 and 2, samples of cells were also taken at various timepoints as shown in Figures 6 and Supplementary Figure 4, lysed and immunoblotted as described [21], with rabbit polyclonal phospho-Chk2 (Thr68) (Cell Signaling, catalog \# 2661). Chk1 was immunoblotted with rabbit monoclonal phospho-Chk1 (Ser345) (Cell Signaling, cat \# 2348). Chk1 and 2 levels were normalized against mouse monoclonal alpha tubulin, (Abcam, ab80779, clone DM1A).

\section{Genomic instability analysis}

Chromosomal aberrations were assessed as previously described [22]. Cells were harvested by mitotic shake-off and lysed in $0.75 \% \mathrm{KCl}$ at $37^{\circ} \mathrm{C}$ for 30 minutes before fixing in Carnoy's Fixative (75\% methanol, $25 \%$ acetic acid). Images were taken using Spot Camera software (Diagnostic Instruments). Metaphase spreads were de-identified and scored by eye for chromosomal fusions, breaks, and fragments. Asynchronous MCF10A cells were treated with ionizing radiation or $200 \mu \mathrm{M} \mathrm{H}_{2} \mathrm{O}_{2}$ on ice for 20 mins while in exponential growth. Fresh media containing $6 \mu \mathrm{g} / \mathrm{ml}$ Cytochalasin-B was added directly after exposure, followed by $24 \mathrm{hr}$ incubation at $37^{\circ} \mathrm{C}$. Cells were then trypsinized, washed, and resuspended in $7 \mathrm{ml} 0.075 \mathrm{M}(0.56 \%)$ potassium chloride for $10 \mathrm{~min}$ at $37^{\circ} \mathrm{C}$, and fixed by adding $3 \mathrm{ml}$ of $100 \%$ methanol for at least $1 \mathrm{hr}$ at room temperature, followed by fixation twice in acetic acid/methanol (1:3). Fixed cells were dropped onto wet slides, dried and stained with $10 \mu \mathrm{g} / \mathrm{ml}$ Acridine Orange (AO) in PBS for $20 \mathrm{~min}$, and rinse briefly in water. A coverslip was placed over the cells in a drop of water on the slide and scoring was done immediately on an Olympus BX50 fluorescence microscope with a FITC (488 emission) filter cube. More water was added to the edge of the coverslip to prevent drying out during scoring. The slides were coded and scored blindly. For each sample, micronucleus induction in 100 binucleated cells was scored following the criteria described in detail in Fenech [35].

\section{Ouabain mutagenesis assay}

MCF10A cells expressing WT or G83D NEIL1 in exponential growth. Cells were trypsinized and plated in $10 \mathrm{~cm}$ dishes at various concentrations. Cells were allowed to attach overnight and ouabain (Sigma) was added to a final concentration of $100 \mathrm{nM}$. After 3 weeks of growth, cells were stained with $0.25 \%$ crystal violet (Sigma). Colonies were counted and mutagenesis was calculated by dividing the total number of ouabain resistance colonies by the number of surviving colonies on plates grown in the absence of ouabain.

\section{Abbreviations}

Propidium Iodide, PI; Hemagglutinin tag, HA; Base excision repair, BER; wild-type, WT; doublestrand breaks, DSBs; reactive oxygen and nitrogen species, RONs; apurinic/apyriminidinic endonuclease I, APE I; DNA polymerase beta, pol $\beta$; DNA ligase $3 \alpha$, LIG $3 \alpha$; X-Ray Cross-Complimenting 1, XRCC1; deoxyribose phosphate, dRP; Gly83 to Asp83, G83D; spiroiminohydantoin, Sp; guanidinohydantoin, Gh; thymine glycol, Tg; single-stranded DNA, ssDNA; DNA polymerase $\delta$, Pol $\delta$; phosphate buffered saline, PBS; tris buffered saline, TBS; bovine serum albumin, BSA; dithiothreitol, DTT; Acridine Orange, AO; SNP, single nucleotide polymorphism.

\section{Author contributions}

HG performed experiments; SK performed experiments; JD analyzed TCGA data and results; LV performed experiments; AN performed experiments; SW provided advice; AP performed experiments; SD provided advice; JS designed managed the research and prepared the manuscript. 


\section{CONFLICTS OF INTEREST}

The authors declare no conflicts of interest.

\section{FUNDING}

NCI P01 CA098993 (JBS, SD, SSW); NIEHS 5K99ES024417-02/ 5R00ES024417-04 (AP).

\section{REFERENCES}

1. Barnes DE, Lindahl T. Repair and genetic consequences of endogenous DNA base damage in mammalian cells. Annu Rev Genet. 2004; 38:445-476.

2. Wallace SS, Murphy DL, Sweasy JB. Base excision repair and cancer. Cancer Lett. 2012; 327:73-89.

3. Nemec AA, Wallace SS, Sweasy JB. Variant base excision repair proteins: contributors to genomic instability. Semin Cancer Biol. 2010; 20:320-328.

4. Wiederhold L, Leppard JB, Kedar P, Karimi-Busheri F, Rasouli-Nia A, Weinfeld M, Tomkinson AE, Izumi T, Prasad R, Wilson SH, Mitra S, Hazra TK. AP endonucleaseindependent DNA base excision repair in human cells. Mol Cell. 2004; 15:209-220.

5. Liu M, Bandaru V, Bond JP, Jaruga P, Zhao X, Christov PP, Burrows CJ, Rizzo CJ, Dizdaroglu M, Wallace SS. The mouse ortholog of NEIL3 is a functional DNA glycosylase in vitro and in vivo. Proc Natl Acad Sci U S A. 2010; 107:4925-4930.

6. Krokeide SZ, Laerdahl JK, Salah M, Luna L, Cederkvist FH, Fleming AM, Burrows CJ, Dalhus B, Bjoras M. Human NEIL3 is mainly a monofunctional DNA glycosylase removing spiroimindiohydantoin and guanidinohydantoin. DNA Repair (Amst). 2013; 12:1159-1164.

7. Hazra TK, Izumi T, Boldogh I, Imhoff B, Kow YW, Jaruga P, Dizdaroglu M, Mitra S. Identification and characterization of a human DNA glycosylase for repair of modified bases in oxidatively damaged DNA. Proc Natl Acad Sci U S A. 2002; 99:3523-3528.

8. Dou H, Theriot CA, Das A, Hegde ML, Matsumoto Y, Boldogh I, Hazra TK, Bhakat KK, Mitra S. Interaction of the human DNA glycosylase NEIL1 with proliferating cell nuclear antigen. The potential for replication-associated repair of oxidized bases in mammalian genomes. The J Biol Chem. 2008; 283:3130-3140.

9. Hegde ML, Theriot CA, Das A, Hegde PM, Guo Z, Gary RK, Hazra TK, Shen B, Mitra S. Physical and functional interaction between human oxidized base-specific DNA glycosylase NEIL1 and flap endonuclease 1. The J Biol Chem. 2008; 283:27028-27037.

10. Hegde ML, Hegde PM, Bellot LJ, Mandal SM, Hazra TK, Li GM, Boldogh I, Tomkinson AE, Mitra S. Prereplicative repair of oxidized bases in the human genome is mediated by NEIL1 DNA glycosylase together with replication proteins. Proc Natl Acad Sci U S A. 2013; 110:E3090-3099.

11. Theriot CA, Hegde ML, Hazra TK, Mitra S. RPA physically interacts with the human DNA glycosylase NEIL1 to regulate excision of oxidative DNA base damage in primertemplate structures. DNA Repair (Amst). 2010; 9:643-652.

12. Bandaru V, Blaisdell JO, Wallace SS. Oxidative DNA glycosylases: recipes from cloning to characterization. Methods Enzymol. 2006; 408:15-33.

13. Forsbring M, Vik ES, Dalhus B, Karlsen TH, Bergquist A, Schrumpf E, Bjoras M, Boberg KM, Alseth I. Catalytically impaired hMYH and NEIL1 mutant proteins identified in patients with primary sclerosing cholangitis and cholangiocarcinoma. Carcinogenesis. 2009; 30:1147-1154.

14. Prakash A, Carroll BL, Sweasy JB, Wallace SS, Doublie $\mathrm{S}$. Genome and cancer single nucleotide polymorphisms of the human NEIL1 DNA glycosylase: activity, structure, and the effect of editing. DNA Repair (Amst). 2014; 14:17-26.

15. Roy LM, Jaruga P, Wood TG, McCullough AK, Dizdaroglu M, Lloyd RS. Human polymorphic variants of the NEIL1 DNA glycosylase. The J Biol Chem. 2007; 282:15790-15798.

16. Eckenroth BE, Fleming AM, Sweasy JB, Burrows CJ, Doublie S. Crystal structure of DNA polymerase beta with DNA containing the base lesion spiroiminodihydantoin in a templating position. Biochemistry. 2014; 53:2075-2077.

17. Aller P, Rould MA, Hogg M, Wallace SS, Doublie S. A structural rationale for stalling of a replicative DNA polymerase at the most common oxidative thymine lesion, thymine glycol. Proc Natl Acad Sci U S A. 2007; 104:814-818.

18. McNeill DR, Paramasivam M, Baldwin J, Huang J, Vyjayanti VN, Seidman MM, Wilson DM, 3rd. NEIL1 responds and binds to psoralen-induced DNA interstrand crosslinks. The J Biol Chem. 2013; 288:12426-12436.

19. Sweasy JB, Lang T, DiMaio D. Is base excision repair a tumor suppressor mechanism? Cell Cycle. 2006; 5:250-259.

20. Sweasy JB, Lang T, Starcevic D, Sun KW, Lai CC, Dimaio D, Dalal S. Expression of DNA polymerase \{beta\} cancer-associated variants in mouse cells results in cellular transformation. Proc Natl Acad Sci U S A. 2005; 102:14350-55.

21. Galick HA, Kathe S, Liu M, Robey-Bond S, Kidane D, Wallace SS, Sweasy JB. Germ-line variant of human NTH1 DNA glycosylase induces genomic instability and cellular transformation. Proc Natl Acad Sci U S A. 2013; 110:14314-14319.

22. Yamtich J, Nemec AA, Keh A, Sweasy JB. A germline polymorphism of DNA polymerase Beta induces genomic instability and cellular transformation. PLoS Genet. 2012; 8:e1003052.

23. Marsden CG, Jensen RB, Zagelbaum J, Rothenberg E, Morrical SW, Wallace SS, Sweasy JB. The 
Tumor-Associated Variant RAD51 G151D Induces a Hyper-Recombination Phenotype. PLoS Genet. 2016; 12:e1006208

24. Nemec AA, Bush KB, Towle-Weicksel JB, Taylor BF, Schulz V, Weidhaas JB, Tuck DP, Sweasy JB. Estrogen Drives Cellular Transformation and Mutagenesis in Cells Expressing the Breast Cancer-Associated R438W DNA Polymerase Lambda Protein. Mol Cancer Res. 2016; 14:1068-1077.

25. Kawabata T, Luebben SW, Yamaguchi S, Ilves I, Matise I, Buske T, Botchan MR, Shima N. Stalled fork rescue via dormant replication origins in unchallenged $\mathrm{S}$ phase promotes proper chromosome segregation and tumor suppression. Mol Cell. 2011; 41:543-553.

26. Naim V, Rosselli F. The FANC pathway and BLM collaborate during mitosis to prevent micro-nucleation and chromosome abnormalities. Nat Cell Biol. 2009; 11:761-768.

27. Lukas C, Savic V, Bekker-Jensen S, Doil C, Neumann B, Pedersen RS, Grofte M, Chan KL, Hickson ID, Bartek J, Lukas J. 53BP1 nuclear bodies form around DNA lesions generated by mitotic transmission of chromosomes under replication stress. Nat Cell Biol. 2011; 13:243-253.

28. Neelsen KJ, Zanini IM, Herrador R, Lopes M. Oncogenes induce genotoxic stress by mitotic processing of unusual replication intermediates. J Cell Biol. 2013; 200:699-708.

29. Cortez D. Preventing replication fork collapse to maintain genome integrity. DNA Repair (Amst). 2015; 32:149-157.
30. Fugger K, Chu WK, Haahr P, Kousholt AN, Beck H, Payne MJ, Hanada K, Hickson ID, Sorensen CS. FBH1 co-operates with MUS81 in inducing DNA double-strand breaks and cell death following replication stress. Nat Commun. 2013; 4:1423.

31. Fugger K, Mistrik M, Neelsen KJ, Yao Q, Zellweger R, Kousholt AN, Haahr P, Chu WK, Bartek J, Lopes M, Hickson ID, Sorensen CS. FBH1 Catalyzes Regression of Stalled Replication Forks. Cell Rep. 2015; 10: 1749-57.

32. Jeong YT, Rossi M, Cermak L, Saraf A, Florens L, Washburn MP, Sung P, Schildkraut CL, Pagano M. FBH1 promotes DNA double-strand breakage and apoptosis in response to DNA replication stress. J Cell Biol. 2013; 200:141-149.

33. Thullberg M, Stromblad S. Anchorage-independent cytokinesis as part of oncogenic transformation? Cell Cycle. 2008; 7:984-988.

34. Blaisdell JO, Wallace SS. Rapid determination of the active fraction of DNA repair glycosylases: a novel fluorescence assay for trapped intermediates. Nucleic Acids Res. 2007; 35:1601-1611.

35. Fenech $\mathrm{M}$. The cytokinesis-block micronucleus technique: a detailed description of the method and its application to genotoxicity studies in human populations. Mutat Res. 1993; 285:35-44. 